\title{
Güzel Sanatlar Lisesi Müzik Alanı Özel Gereksinimli Öğrencilerin Öğrenim Süreçlerinin Müzik Öğretmenlerinin Görüşleri Çerçevesinde Değerlendirilmesi
}

Zeynep Özer ${ }^{1}$

\author{
Rasim Erol Demirbatır ${ }^{2}$
}

Type/Tür:

Research/Araştırma

Received/Geliş Tarihi:

September 18/ 18 Eylül 2020

Accepted/Kabul Tarihi:

January 21/ 21 Ocak 2021

Page numbers/Sayfa No: 844 866

Corresponding

Author/Illetişimden Sorumlu

Yazar:

811941004@ogr.uludag.edu.tr

\section{$\checkmark$ iThenticate}

This paper was checked for plagiarism using iThenticate during the preview process and before publication. / $\mathrm{Bu}$ çalışma ön inceleme sürecinde ve yayımlanmadan önce iThenticate yazılımı ile taranmiştır.

Copyright $@ 2017$ by Cumhuriyet University, Faculty of Education. All rights reserved.

\section{Öz}

$\mathrm{Bu}$ araştırmada güzel sanatlar liselerinde görev yapan müzik öğretmenlerinin müzik alanı özel gereksinimli öğrencilerin okula giriş ve öğrenim süreçlerine yönelik görüşlerinin belirlenmesi amaçlanmıştır. Araştırmanın çalışma grubunu 2019-2020 eğitim-öğretim yılında Bursa Zeki Müren Güzel Sanatlar Lisesi'nde görev yapan 7 müzik öğretmeni oluşturmaktadır. Çalışma grubundaki öğretmenlerin 2'si müziksel işitme ve okuma dersini, 5 'i ise çalgı derslerini yürütmektedir. Çalışma grubu belirlenirken amaca yönelik örnekleme yöntemi kullanılmıştır. Araştırmada nitel yöntem kullanılarak yarı yapılandırılmış görüşme formu ve kişisel bilgi formu yoluyla müzik öğretmenlerinden elde edilen veriler içerik analizi yöntemi ile çözümlenmiştir. Yönlendirilmiş içerik analizinde ilk kodlar önceden oluşturulabilmektedir. Ayrıca araştırma sırasında da gerekli görüldüğünde yeni kategori ve kodlar eklenebilmektedir. Müzik öğretmenleriyle yapılan görüşmeler doğrultusunda özel gereksinimli öğrencilerin yetenek sinavi kriterlerinin ve kontenjanlarının yine bu öğrencilerin özel durumları göz önünde bulundurularak belirlenmesi, bu öğrencilerin ilgi ve yetenekleri doğrultusunda istedikleri okullarda akranları ile birlikte eğitim almalarının önemi, destek eğitim odalarının oluşturulması, bireyselleştirilmiş eğitim programlarının hazırlanarak rehberlik servisi tarafından gerekli yönlendirmelerin yapılması, ölçme ve değerlendirme süreçlerinin yine bu öğrencilerin gelişim özellikleri, yapabilirlik düzeyleri ve sınıf seviyeleri göz önüne alınarak hazırlanması, özel gereksinimli öğrenciler ile çalışan öğretmenlerin yeterliliklerinin geliştirilmesi için hizmet içi eğitimlere katılımlarının sağlanması, bu alanda eğitim verecek uzman müzik öğretmenlerinin yetiştirilmesi ve bu öğretmenlere ekonomik teşvikler verilmesi, okulların teknik altyapılarının iyileştirilmesi ve donanımlı personellerin bulundurulması araştırma sonunda oluşturulan öneriler arasında yer almaktadır.

Anahtar Kelimeler: Özel gereksinimli öğrenciler, özel eğitim, müzik eğitimi, özel yetenek, öğrenme güçlüğü.

\section{Suggested APA Citation/Önerilen APA Atıf Biçimi}

Özer, Z., \& Demirbatır, R., S. (2021). Güzel Sanatlar Lisesi müzik alanı özel gereksinimli öğrencilerin öğrenim süreçlerine yönelik müzik öğretmenlerinin görüşleri çerçevesinde değerlendirilmesi Cumhuriyet International Journal of Education, 10(2), 844-866. http://dx.doi.org/10.30703/cije.796803

\footnotetext{
1 Doktora Öğrencisi, Uludağ Üniversitesi, Güzel Sanatlar Eğitimi, Müzik Eğitimi Bölümü, Bursa/Türkiye Phd Student, Uludağ University, Fine Arts Education, Music Education Department, Bursa/Turkey e-mail: $111941004 @$ ogr.uludag.edu.tr ORCID ID: orcid.org/0000-0001-5884-3367

2 Doç. Dr., Uludağ Üniversitesi, Güzel Sanatlar Eğitimi, Müzik Eğitimi Bölümü, Bursa/Türkiye Assoc. Prof. Dr., Uludağ University, Fine Arts Education, Music Education Department, Bursa/Turkey e-mail: redemir@uludag.edu.tr ORCID ID: orcid.org/0000-0002-9472-3001
} 


\title{
Evaluation of the Learning Process of Student with Special Needs in the Music Field of Fine Arts High School within the Framework of Music Teachers' Views
}

\begin{abstract}
In this study, it was aimed to determine the views of music teachers working in fine arts high schools about the entrance and learning processes of students with special needs in the field of music. The study group of the research consists of 7 music teachers working at Bursa Zeki Müren Fine Arts High School in the 2019-2020 academic year. 2 of the teachers in the study group teach musical hearing and reading courses and 5 of them teach instrument courses. Purposeful sampling method was used while determining the study group. In the study, data obtained from music teachers through semi-structured interview form and personal information form by using qualitative method were analysed by content analysis method. In the directed content analysis, the initial codes can be created in advance. In addition, new categories and codes can be added when deemed necessary during the research. Determining the talent exam criteria / quotas of the students with special needs by considering the special situations of these students, ensuring that these students receive education with their peers in the schools they want in line with their interests and abilities, establishing resource rooms, preparing individualized education programs and directing them by the counselling service, preparing the assessment and evaluation processes of these students by considering their developmental characteristics, skills and grade levels, ensuring participation of teachers in in-service courses in order to increase the competence of teachers working with special needs students, training music teachers who are experts in this field and providing economic incentives to these teachers, improving the technical infrastructure of schools and having well-equipped staff in schools are among the suggestions made in line with the findings obtained as a result of the interviews with music teachers.
\end{abstract}

Keywords: Students with special needs, special education, music education, special talent, learning difficulty.

\section{Giriş}

Eğitimde her birey ayrı ayrı temel alınarak değerlendirilmelidir. Öyleyse eğitim ortamı, her bireye hitap edecek farklı içeriklerden oluşan, bireyin kendini özgürce ifade edebileceği şartların sunulduğu bir yapıya sahip olmalıdır (Sönmez, 2002, s.117). Özellikle özel gereksinimli bireylerin eğitimi söz konusu olduğunda bu durum daha da dikkate alınması gereken bir yaklaşım olarak karşımıza çıkmaktadır.

Ülkemizde özel gereksinimli öğrencilerin ihtiyaç düzeylerine göre farklı eğitim kurumları bulunmaktadır. Gerekli gelişimsel tanılamalardan sonra bu öğrenciler ilgili kurumlara yönlendirilmektedir. Ancak akranları ile birlikte eğitimlerine devam edebilecek düzeyde bulunan öğrenciler normal gelişim gösteren yaşıtları ile birlikte kaynaştırma eğitimi adıyla öğrenimlerini sürdürebilmektedir. Kaynaştırma eğitiminin doğru ve tam uygulandığında özel gereksinimli öğrencilerin sosyal ve akademik olarak ihtiyaçlarını karşılama yönünde oldukça etkili bir uygulama olduğu düşünülmektedir (Dikmen, 2018, s.105). Kaynaştırma eğitimi her çocuğun bulunduğu ortamda en iyi eğitimi almasının önemini vurgulayan, özel gereksinimi olsun veya olmasın bütün çocukların sosyal ve akademik başarı elde etme ve toplum içinde bir birey olma fırsatı sağlama düşüncesiyle oluşturulan bir eğitim modelidir (Sucuoğlu, 2006, s.4). Kaynaştırma eğitimi uygulamaları ilk olarak 1975 yılında Amerika Birleşik Devletleri'nde 'en az kısıtlayıcı eğitim ortamı' kavramıyla 
'Engelliler için Eğitim Yasası' nda geçmektedir. Bu kavramla birlikte özel gereksinimli öğrencilerin bireysel özelliklerine bağlı olarak akranları ile mümkün oldukça aynı ortamda bir araya gelmesinin ve eğitim ortamlarının oluşturulmasının gerekliliği vurgulanmıştır (Batu, 2000, s.7).

Türk Milli Eğitimi'nin genel amaçları ve temel ilkeleri doğrultusunda 1997 yılında 573 Sayılı Kanun Hükmünde Kararname yayınlanarak özel eğitim gerektiren bireylerin genel ve mesleki eğitim görme haklarına yönelik esaslar düzenlenerek belirlenmiştir. Bu kararname özel eğitim alanındaki çalışmalara rehberlik etmesi açısından oldukça önemlidir (Melekoğlu ve Sak, 2017, s.16). Özel Eğitim Hizmetleri Yönetmeliği'nin 4. maddesinde özel gereksinimli öğrenciler veya bütünleştirme uygulamaları ile ilgili olarak; "özel eğitim ihtiyacı olan bireylerin her tür ve kademede diğer bireylerle etkileşim içinde bulunmaların ve eğitim amaçların en üst düzeyde gerçekleştirmelerini sağlamak amactyla bu bireylere destek eğitim hizmetleri de sunularak akranlarıla birlikte tam zamanlı ya da özel eğitim sinıflarında yarı zamanlı verilen eğitimi ifade eder" açıklaması yapılmıştır (MEB, 2020a).

Bireyin zayıf yönlerinin performansını olumsuz olarak etkilediği düşünülmekte ancak güçlü yönlerinin nasıl değerlendirileceği ve geliştirileceği göz ardı edilmektedir. Özel gereksinimli aynı zamanda özel yetenekli bireyler bu duruma örnek olarak gösterilebilir. Özel gereksinimli bireylerin aynı zamanda özel yeteneklerinin olma ihtimali toplum içinde zor anlaşılır bir durum olmasına rağmen son zamanlarda bu konuyla ilgili özel çalışmalara yer verilmiştir (Melekoğlu ve Sak, 2017, s.256). İlgili çalışmalarda, fiziksel ve zihinsel olarak yaşadıkları zorluklara rağmen üstün yeteneklere sahip olan bu çocuklara iki kere farklı tanımlaması yapılmaktadır. İki kere farklı öğrencilerin fiziksel engelleri görme, işitme ya da bedensel, zihinsel engelleri ise öğrenme ile ilgili yaşadıkları sorunları içermektedir (Emir, 2017, s.303).

Özel gereksinimli ve özel yetenekli öğrencilerin eğitim süreçlerinde kullanılacak programlarla ilgili Wong ve Chik (2016) tarafından gerçekleştirilen bir çalışmada, kapsayıcı (bütünleştirici) eğitim yaklaşımının bu öğrencilerin müzik eğitimlerinde de kullanılmasının yararlı olacağı belirtilmiştir. Kapsayıcı eğitim yaklaşımında özel gereksinimli öğrencilerin sosyal, kültürel, eğitimsel, yaşamsal aktivite ve firsatlara tüm toplum üyeleri ve akranlarıyla birlikte eğitim alma hakkı vurgulanmaktadir (Wong ve Chik, 2016, s.133).

Özel gereksinimli öğrencilerin örgün eğitimi içerisinde kendi akranlarıyla birlikte eğitim alırken destekleyici bireyselleştirilmiş programlarında uygulanması bu çocukların gelişimlerine olumlu yönde katkılar sağlamaktadır. Draper (2020), özel gereksinimli öğrenciler ile çalışan müzik öğretmenlerine yönelik yaptığı çalışmasında bireyselleştirilmiş eğitim programlarının bu çocuklar için uygulanabilecek en uygun program olduğunu belirtmiştir. Bu programların özel gereksinimli öğrenciler için 'yapılması gereken düzenlemeler', 'olması beklenen değişiklikler' ve 'neler yapılacağına ilişkin destekler' olmak üzere üç başlık halinde hazırlanmasının önemini vurgulanmıştır (Draper, 2020, s.43). Ülkemizde özel gereksinimli öğrencilerin eğitiminde kullanılan bireyselleştirilmiş eğitim programı öğrencilerin gözlenmesi, aile ile görüşmeler yapılması, öğrencinin ürün değerlendirmesi, kaba değerlendirme ve ayrıntılı değerlendirme süreçlerinden oluşmaktadır (Tanrıverdi Kış, 2011, s.55). Güven (2011), özel gereksinimli öğrencilere yönelik uygun içerik ve öğretim 
yöntemleriyle zenginleştirilmiş programların uygulanmasının bu çocukların gelişimlerini desteklemek açısından önemli olduğunu belirtmiştir. Emir (2017) ise üstün yetenekli aynı zamanda özel gereksinimli öğrenciler için farklı öğretim programlarının hazırlanmasının bu çocukların zayıf ve kuvvetli yönlerine odaklanmayı sağlaması açısından önemli bulmaktadır. Ayrıca özel gereksinimli öğrencilere ilişkin uzman görüşlerine ihtiyaç duyulduğu ve bu öğrencilerin yeteneklerinin değerlendirilerek gerekli çalışmaların yapılmasının önemi vurgulanmıştır. Eğitimciler tarafından özel gereksinimli öğrencilerin eğitimi düzenli bir plan çerçevesinde yürütüldüğünde bu öğrenciler üzerinde olumlu etkilerinin gerçekleşeceği belirtilmiştir (Darrow, 1999, s.258).

Ülkemizde müzik alanında özel yeteneğe sahip özel gereksinimli öğrencilerin akranları ile birlikte etkileşim içinde bulunarak eğitim alabilecekleri kurumlardan biri güzel sanatlar liseleridir. Güzel sanatlar liseleri her yıl yetenek sınavı ile özel gereksinimli öğrencilere 2 veya 3 kişilik kontenjan ayırmaktadır. Bu öğrenciler de akranları gibi yetenek sınavına girmektedir. Yetenek sınavları ile öğrenci alan okullara başvuru konulu genelgede bu öğrenciler ile ilgili olarak; "Rehberlik ve araştırma merkezleri bünyesinde hizmet veren özel eğitim değerlendirme kurulu karar doğrultusunda özel eğitime ihtiyacı olan ve kaynaştırma yoluyla eğitim alacak öğrenciler komisyon tarafindan bu genelgede belirtilen usul ve esaslara göre kendi aralarinda beceri/yetenek sinavina alınacaktır. Aday öğrencilerden; Rehberlik ve araştırma merkezleri bünyesinde hizmet veren özel eğitim değerlendirme kurulu kararı doğrultusunda özel eğitime ihtiyact olan ve kaynaştırma yoluyla ĕgitim alacak olan öğrenciler yetenek sınav 50 (elli) puan barajını geçmek şartıyla 100 puan üzerinden değerlendirilir. Yetenek sınavın kazanan bu durumdaki öğrenciler, il/ilçe milli eğitim müdürlüklerindeki öğrenci nakil ve yerleştirme komisyonlarnnca yerleştirilecektir." açıklaması yer almaktadır (MEB, 2020b). Güzel sanatlar liselerinin özel gereksinimli öğrencileri tam zamanlı kaynaştırma uygulaması kapsamında eğitim-öğretimlerine devam etmektedir. Tam zamanlı kaynaştırma uygulamasında bu öğrenciler tüm gün boyunca akranlarıyla birlikte örgün eğitiminin içerisinde yer almaktadir (Batu ve Kircaali İftar, 2011, s.9).

Yapılan taramalar 1şığında müzik eğitiminde özel gereksinimli öğrencilerin eğitim uygulamaları ile ilgili birçok araştırmanın yapıldı ğı belirlenmiştir. Ancak özel gereksinimli ve aynı zamanda özel yeteneğe sahip olan öğrenciler ile ilgili çalışmaların sayıca az olduğu saptanmıştır. Bu amaçla müzik öğretmenlerinin güzel sanatlar lisesi müzik alanı özel gereksinimli öğrencilerin öğrenim sürecine yönelik görüşlerinin alınması ve bu görüşler doğrultusunda varsa eksikliklerin giderilmesine yönelik önerilerin geliştirilmesi ile sürece olumlu yönde katkı sağlanacağ1 düşünülmektedir. Bu çalışmada süreci yöneten müzik öğretmenlerinden elde edilen görüşler doğrultusunda özel gereksinimli öğrencilere yönelik okula giriş ve eğitim uygulamaları değerlendirilerek ne ölçüde etkili olduğunun saptanması, olumlu ve olumsuz yönlerinin belirlenerek çeşitli çözüm önerilerinin getirilmesi amaçlanmaktadır. Bu amaç doğrultusunda aşağıda belirtilen araştırma sorularına yanıt aranmıştır.

1. Güzel sanatlar liseleri müzik alanına özel gereksinimli öğrenci alımı ile ilgili müzik öğretmenlerinin görüşleri nelerdir? 
2. Güzel sanatlar liseleri müzik alanı özel gereksinimli öğrencilerin eğitimöğretim süreçlerini destekleyecek eğitim uygulamalarına ilişkin müzik öğretmenlerinin görüşleri nelerdir?

3. Güzel sanatlar liseleri müzik alanı özel gereksinimli öğrencilerinin yaşadığ1 zorluklara ilişkin müzik öğretmenlerinin görüşleri nelerdir?

4. Müzik alanı özel gereksinimli öğrencilerinin ölçme değerlendirme sürecine ilişkin müzik öğretmenlerinin görüşleri nelerdir? nelerdir?

5. Müzik öğretmenlerinin özel gereksinimli öğrencilerden beklentileri

Araştırmada elde edilen bulgular 1şığında özel gereksinimli öğrencilerin okula giriş ve öğrenme süreçleri değerlendirilerek karşılaşılan sorunların saptanmasıyla bu öğrencilerin eğitimlerine yönelik olumlu katkıların sağlanacağ1 düşünülmüştür. Bu doğrultuda süreci yöneten öğretmenlerin görüşleri önem arz etmektedir.

\section{Yöntem}

Bu çalışma güzel sanatlar liseleri müzik alanı özel gereksinimli öğrencilerin öğrenme süreçlerine yönelik müzik öğretmenlerinin görüşlerini belirlemek amacıyla görüşme tekniğinin kullanıldığı nitel bir araştırmadır. Durumların altında yatan temel anlam ve kavramlar anlaşılmaya çalışıldığında nitel yaklaşım yöntemleri kullanılmaktadır (Arı, 2019, s.13). Yıldırım ve Şimşek (2000) nitel araştırmayı gözlem, görüşme ve doküman analizi gibi nitel veri toplama araçlarının kullanıldı ğı algıların ve olayların doğal ortamda gerçekçi ve bütüncül bir biçimde ortaya konmasına yönelik bir sürecin izlendiği araştırma yöntemi olarak tanımlamışlardır. Nitel araştırmalarda sıklıkla kullanılan görüşme tekniği ise insanların belli zamanlarda belli konulara karşı tutum ve görüşleri hakkında bilgi toplamak amacıyla gerçekleştirilmektedir (Güler vd., 2015, s.114). Görüşme tekniğinde veriler araştırmacı ile araştırmaya katılan bireyler arasında kurulan ilişki sonucunda elde edilmektedir. Bu teknik uygulanırken dikkat edilmesi gereken en önemli şey araştırmacı ve katılımcılar arasındaki ilişkinin eşitlikçi, açık ve net olmasıdır (Salman Yıkmış, 2020, s.187).

\section{Çalışma Grubu}

$\mathrm{Bu}$ araştırmada çalışma grubu belirlenirken 'amaca yönelik örnekleme' yöntemi kullanılmıştır. Amaca yönelik örnekleme yönteminde amaç araştırmanın önyargılarını azaltarak, geçerlik ve güvenirliğini arttırmaktır (Baltacı, 2018, s.246). Bu nedenle amaca yönelik örneklem seçiminde kritik öneme sahip konuların yani araştırma konusunun doğru ve güvenilir bir şekilde bilgi yönünden zengin birimlerden elde edilmesi önemlidir (Merriam, 2009, s.77). Ayrıca amaca yönelik örnekleme yöntemi sınırlı kaynakların verimli bir şekilde kullanılması için doğru bilgi kaynaklarının belirlenmesi ve seçilmesi için kullanılan en uygun yöntemlerden biridir (Yağar ve Sema, 2018, s.4).

Araştırmanın çalışma grubunu Bursa Zeki Müren Güzel Sanatlar Lisesi'nde görev yapmakta olan 7 müzik öğretmeni oluşturmaktadır. Bunlardan 2'si müziksel 
okuma ve işitme dersine girmekte olup, 5’ i ise bireysel çalg1 öğretmenidir. Bu okulda öğrenim gören özel gereksinimli öğrencilerle ders yapan tüm müzik öğretmenleri çalışma grubunda yer almaktadır.

Tablo 1'de araştırmanın çalışma grubunun demografik bilgileri yer almaktadır. Buna göre, öğretmenlerden 3'ünün yüksek lisans mezunu olduğu, 6 öğretmenin uzun yıllar özel yetenekli öğrencilerle çalıştığı, sadece bir öğretmenin ise uzun yıllar özel gereksinimli öğrenciler ile çalıştığı görülmektedir.

Tablo 1

Çalışma Grubunun Demografik Bilgileri

\begin{tabular}{llllll}
\hline Katılımcılar & Cinsiyet & $\begin{array}{l}\text { Öğrenim } \\
\text { Durumu }\end{array}$ & Hizmet Yılı & $\begin{array}{l}\text { Güzel Sanatlar } \\
\text { Liselerinde } \\
\text { Hizmet Yllı }\end{array}$ & $\begin{array}{l}\text { Özel } \\
\text { Gereksinimli } \\
\text { Öğrencilerle } \\
\text { Çalışma Y1lı }\end{array}$ \\
\hline Öğretmen 1 & Erkek & Lisans & 22 & 22 & 1 \\
Öğretmen 2 & Erkek & Lisans & 21 & 15 & 1 \\
Öğretmen 3 & Erkek & Y. Lisans & 20 & 15 & 1 \\
Öğretmen 4 & Erkek & Y. Lisans & 22 & 2 & 20 \\
Öğretmen 5 & Kadın & Y. Lisans & 13 & 10 & 3 \\
Öğretmen 6 & Kadın & Lisans & 20 & 10 & 3 \\
Öğretmen 7 & Kadın & Lisans & 19 & 14 & 4 \\
\hline
\end{tabular}

\section{Veri Toplama Araçları}

Araştırma verileri araştırmacılar tarafından uzman görüşü alınarak geliştirilen yarı yapılandırılmış görüşme formu kullanılarak elde edilmiştir. Yarı yapılandırılmış görüşmeler katılımcının görüşme sırasında kendini rahat bir şekilde ifade edebilmesine imkân tanıyarak araştırma konusuyla ilgili derinlemesine bilgi edinmeyi kolaylaştırmaktadır (Büyüköztürk vd., 2020, s.159). Araştırmacının konuya yönelik elde etmek istediği verileri kapsamlı bir şekilde toplamaya ve görüşme esnasında değişen koşullara göre soruların değişime gitmesine olanak sağlaması açısından yarı yapılandırılmış görüşme yöntemi nitel araştırmalarda sıklıkla kullanılmaktadır (Güler vd., 2015, s.115). Yarı yapılandırılmış görüşmede bireyler ve koşullara bakarak soruların sırası değiştirilebilmekte ayrıca gerektiğinde sorular daha ayrıntılı açıklanabilmektedir (Çepni, 2018, s.181).

Görüşme formu. Bu çalışmada güzel sanatlar lisesinde görev yapan müzik öğretmenlerine, müzik alanı özel gereksinimli öğrencilerinin öğrenim süreçlerine yönelik görüşlerini elde etmek amacıyla 10 soru yöneltilmiştir. Ayrıca okulun rehberlik öğretmeni ile görüşülerek özel gereksinimli öğrenciler hakkında görüş alınmıştır.

Kişisel bilgi formu. Çalışmada güzel sanatlar lisesinde görev yapan müzik öğretmenlerinin cinsiyetleri, öğrenim durumları, görevde hizmet yılları, güzel sanatlar liselerinde ve özel gereksinimli öğrenciler ile çalışma sürelerini belirlemek amacıyla kişisel bilgi formu hazırlanmıştır.

\section{Verilerin Analizi}

Nitel araştırmada veri analizi, verilerin organize edilerek kodlanması, kodların temalarla gruplandırılması ve bulguların tablolar halinde sunularak tartışılmasıdır (Bütün ve Demir, 2020, s.182). Bu çalışmada elde edilen veriler içerik analizi yöntemi 
kullanılarak çözümlenmiştir. İçerik analizinde, veri toplama aracıyla elde edilen bilgilerin derinlemesine incelenerek elde edilen bulguların kategorilere ayrilmasıyla bulgular aralarındaki ilişki ve bağlantıları kurma işlemi gerçekleştirilmektedir (Sönmez ve Alacapınar, 2019, s.280) İçerik analizinin temel amacı, elde edilen verileri tanımlayacak veya açıklayacak kavramlara ulaşmaktır. Bu süreçte betimsel olarak fark edilemeyen durumlar içerik analizi ile birlikte ortaya çıkarılabilmektedir (Yıldırım ve Şimşek, 2000, s.162). Kodlama şekillerine göre içerik analizleri farklılıklar göstermektedir. Araştırmanın teori ve literatürüne göre ilk kodlamaların çalışmaya başlanmadan önce oluşturulmasına yönlendirilmiş içerik analizi denilmektedir. Yönlendirilmiş içerik analizinde ihtiyaç duyulursa çalışma sırasında da yeni kategori ve kodlar eklenebilmektedir (Güler vd., 2015, s.344). Bu çalışmada yönlendirilmiş içerik analizi kullanılmıştır. Tema, kategori ve kodlar önceden belirlenmiş kavramlar doğrultusunda oluşturulmuştur.

Tablo 2

Müzik Öğretmenlerinin Müzik Alanı Özel Gereksinimli Öğrencilerin Öğrenim Süreçlerine Yönelik Görüşleri Doğrultusunda Oluşturulan Tema, Kategori ve Kodlar

\begin{tabular}{|c|c|c|}
\hline Temalar & Kategoriler & Kodlar \\
\hline \multirow[t]{3}{*}{ Yetenek Sinavı } & & Kriterler \\
\hline & & Kontenjan \\
\hline & & İlgi ve yetenek \\
\hline \multirow[t]{3}{*}{ Uygulama } & Program & Destek Eğitim Odası \\
\hline & & Bireyselleştirilmiş Eğitim Planı \\
\hline & Rehberlik Servisi & Yönlendirme \\
\hline \multirow[t]{10}{*}{ Beklentiler } & Kişisel Gelişim & Uyum sağlama \\
\hline & & Sosyal İlişkileri geliştirme \\
\hline & & Kolektif çalışmaların parçası \\
\hline & & olabilme \\
\hline & & Temel becerileri geliştirme \\
\hline & & Mutlu ve yararlı hissedebilme \\
\hline & Performans & İşitme \\
\hline & & Teori \\
\hline & & Solfej \\
\hline & & Çalgi hakimiyeti \\
\hline \multirow[t]{4}{*}{ Ölçme/Değerlendirme } & & Sinıf seviyesi \\
\hline & & Gelişim özellikleri \\
\hline & & Yapabilirlik düzeyi \\
\hline & & Gözlem raporu \\
\hline \multirow[t]{9}{*}{ Karşılaşılan Zorluklar } & Öğrenciler açısından & Dikkat eksikliği \\
\hline & & Güdülenmekte zorlanma \\
\hline & & Sosyal uyumsuzluk \\
\hline & & İletişim kurma becerisi \\
\hline & & Akran zorbalığı \\
\hline & & Bireysel çalışma problemi \\
\hline & & Disiplin sorunları \\
\hline & Öğretmenler açısından & Özel alan yetersizliği \\
\hline & & Bireysel çalışma \\
\hline \multirow[t]{4}{*}{ Öneriler } & Özel Eğitim & Hizmet içi eğitim \\
\hline & & Özel öğretim programı \\
\hline & & Özel öğretim yöntemleri \\
\hline & Öğretmen Motivasyonu & Uzman müzik öğretmenleri \\
\hline
\end{tabular}


Tablo 2'de müzik öğretmenleri ile yapılan görüşmeler doğrultusunda elde edilen veriler 1şığında uzman görüşü alınarak oluşturulan tema, kod ve kategoriler yer almaktadır. Bu çalışmada 6 tema başlığ 1 altında 9 kategori ve 35 kod tespit edilmiştir. İçerik analizinin güvenirliği yapılan kodlama işlemine bağlıdır. Bu çalışmada müzik öğretmenleri ile yapılan görüşmeler doğrultusunda önceden belirlenen kavramlar doğrultusunda oluşturulan tema kategori ve kodlar uzman görüşü alınarak değerlendirilmiştir. Uzmanların arasındaki uyum sonucunun (Güvenirlik= Uzlaşma sayısı/ (Uzlaşma +uzlaşmama sayısı)) \%70 den yüksek olması beklenmektedir (Tavşancil ve Aslan, 2001, s.81). Araştırma görüş alınan tüm uzmanlar belirlenen tema, kod ve kategorileri uygun bulmuşlardır.

\section{Araştırmanın Etik İzinleri}

Yapılan bu çalı̧̧mada "Yükseköğretim Kurumları Bilimsel Araştırma ve Yayın Etiği Yönergesi" kapsamında uyulması belirtilen tüm kurallara uyulmuştur. Yönergenin ikinci bölümü olan "Bilimsel Araştırma ve Yayın Etiğine Aykırı Eylemler" başlığı altında belirtilen eylemlerden hiçbiri gerçekleştirilmemiştir.

Etik kurul izin bilgileri

Etik değerlendirmeyi yapan kurul ad 1 = Uludağ Üniversitesi Sosyal ve Beşerî

Bilimler Araştırma ve Yayın Etik Kurulu

Etik değerlendirme kararının tarihi $=3$ Temmuz 2020

Etik değerlendirme belgesi sayı numarası $=2020-04$

\section{Bulgular}

Bu bölümde Bursa Zeki Müren Güzel Sanatlar Lisesi'nde görev yapan müzik öğretmenlerinin müzik alanı özel gereksinimli öğrencilerin öğrenim süreçlerine yönelik görüşleri doğrultusunda elde edilen bulgulara yer verilmiştir. Elde edilen bulgular doğrultusunda yetenek sınavı, uygulama, beklenti, ölçme/değerlendirme, süreç/yaşanılan zorluklar ve öneriler temaları elde edilmiştir. Elde edilen temalar ilgili başlıklar altında farklı tablolar halinde verilerek değerlendirilmiştir.

\section{Müzik Alanı Özel Gereksinimli Öğrencilerin Öğrenim Süreçlerine İlişkin Müzik Öğretmenlerinin Görüşleri Yetenek Sınavı Teması Bulguları}

Güzel sanatlar lisesi müzik öğretmenlerinin müzik alanı özel gereksinimli öğrencilerin yetenek sinavı ile ilgili görüşleri Tablo 3'te sunulmuştur.

Tablo 3

Müzik Öğretmenlerinin Müzik Alanı Özel Gereksinimli Öğrencilerin Yetenek Sınavına Yönelik Görüşleri Doğrultusunda Oluşturulan Tema ve Kodlar

\begin{tabular}{lll}
\hline Tema & Kodlar & Ögrretmenler \\
\hline \multirow{3}{*}{ Yetenek sinav1 } & Kriterler & Ö3, Ö6, Ö7 \\
& Kontenjan & Ö3, Ö1, Ö5 \\
& İlgi ve yetenek & Ö2, Ö4, Ö7 \\
\hline
\end{tabular}


Tablo 3 incelendiğinde öğretmenlerin müzik alanı özel gereksinimli öğrencilerin yetenek sınavına yönelik görüşlerinde sınav kriterleri, kontenjanları ve öğrencilerin ilgi ve yeteneklerinin tespit edilmesinin ön plana çıktığı görülmektedir. Öğretmenlerin "yetenek sınavı" temasına ilişkin görüşleri aşağıda verilmiştir.

Yetenek sınavı kriterleri ile ilgili öğretmen görüşleri: "Kaynaştırma öğrencileri için ayr bir yetenek sınav kriteri ayarlanmalı ve diğer ögrenciler ile aynı kriterlerine göre değerlendirilmemelidir (Ö3). ......ve bu kriterlerin ögrrencilerin özel durumları göz önünde bulundurularak oluşturulması gerektiğini düşünüyorum (Ö6). Yetenek sınavı kriterlerinin bu ögrencilerin özel durumları göz önüne alınarak değerlendirilmesi gerektiğini düşünüyorum (Ö7).

Yetenek sınavı kontenjan durumları hakkında öğretmen görüşleri: Özel öğretim kontenjanı belirlenirken kontenjan doldurmak için öğrenci alınmamalıdır (Ö3). Sadece kontenjan sayısının daha sınırl tutulması gerektiğini düşünüyorum (Ö1). Belli kontenjan dahilinde kaynaştırma öğrencilerinin alımın olumlu buluyorum. Çünkü müziksel anlamda geliştiklerini ve bu durumun onlarn kendilerini ifade ediş biçimlerini geliştirdiŏini düşünüyorum (Ö5).

Öğrencilerin ilgi ve yeteneklerine yönelik öğretmen görüşleri: Kaynaştırma ögrencisi alınmasın değerli ve önemli buluyorum, yetenek sinavıyla alınması da doğru bir yaklaşım, öğrencinin asgari düzeyde de olsa girmek istediği alana karşı ilgi ve yeteneğinin tespit edilmesi öğrenim hayatında da mutlu ve verimli olmasını sağlayacaktır (Ö2). Kaynaştırma öğrencileri de diğer öğrenciler gibi öğrencidir. Bu okullarda yetenek, beceri ve ilgilerine göre eğitim ve öğrenim alma hakları vardır (Ö4). Özel gereksinimli öğrencilerin yetenek ve ilgileri doğrultusunda öğrenim görmek istedikleri okullarm stnavların girmelerini olumlu buluyorum (Ö7).

Müzik öğretmenlerinin özel gereksinimli öğrencilerin yetenek sinavlarına yönelik görüşlerine ilişkin elde edilen bulgular doğrultusunda öğretmenlerden Ö3, Ö6 ve Ö7 yetenek sınav kriterlerinin bu öğrencilerin özel gereksinimleri göz önünde bulundurularak gerçekleştirilmesi gerektiğini belirtmişlerdir. Öğretmenlerden Ö3, Ö5 ve Ö7 ise belli kontenjan dahilinde ancak belirtilen kontenjanları doldurma çabası içerisinde olmadan bu okullara özel gereksinimli öğrenci alımının doğru olduğunu düşünmektedirler. Öğretmenlerden Ö2, Ö4 ve Ö7 özel gereksinimli öğrencilerin ilgi ve yetenekleri doğrultusunda bu tür okullara yönlendirilerek eğitim hakkının sağlanması gerektiğini savunmuşlardır.

Müzik Alanı Özel Gereksinimli Öğrencilerin Öğrenme Süreçlerine Yönelik Öğretmen Görüşlerinin Uygulama Teması Bulguları

Güzel sanatlar lisesi müzik öğretmenlerinin müzik alanı özel gereksinimli öğrencilerin öğrenim sürecinde uygulama temasına yönelik görüşleri Tablo 4 'te sunulmuştur. 
Tablo 4

Müzik Öğretmenlerinin Müzik Alanı Özel Gereksinimli Öğrencilerin Eğitim Uygulamalarna Yönelik Görüşleri Doğrultusunda Oluşturulan Tema, Kategori ve Kodlar

\begin{tabular}{llll}
\hline Temalar & Kategoriler & Kodlar & Öğretmenler \\
\hline Uygulama & Program & Destek Eğitim Odas1 & Ö4 \\
& & Uygulamas1 & B̈̈, Ö6, Ö1, Ö7, Ö2, Ö3, \\
& Bireyselleştirilmiş & Ö5 \\
& Eğitim Programı (BEP) & Ö5 \\
& Rehberlik Servisi & Yönlendirme & Ö2, Ö5 \\
\hline
\end{tabular}

Tablo 4 incelendiğinde öğretmenlerden elde edilen veriler doğrultusunda müzik alanı özel gereksinimli öğrencilerin öğrenim sürecinde destek eğitim odası, bireyselleştirilmiş eğitim planı ve yönlendirme uygulamaları ön plana çıkmaktadır. Öğretmenlerin "uygulama" temasına ilişkin görüşleri aşağıda verilmiştir.

Destek eğitim odası uygulamasına yönelik öğretmen görüssleri: Kimi derslerin çok verimli, kimi derslerin de bir fayda sağlamadığın düşünüyorum. Verimli olan derslerde, sinı ortamında kaynaştırma öğrencisine zaman ayrilamama durumunda, destek eğitimi odası saatlerinde gerekli özen gösterilerek kazanım verilebiliyor. Ancak bu tür öğrencilerde kazanım hafizada uzun süre durmuyor (Ö5).

Bireyselleştirilmiş eğitim planına yönelik öğretmen görüşleri: Bireysel derslerimizde bu öğrenciler için özel bireyselleştirilmiş plan hazırlamaktayız (Ö1)........rehber öğretmenin yönlendirmeleriyle bireyselleştirilmiş eğitim planı hazırlyyoruz (Ö2). Her öğrencinin öğrenme seviyesi farkllik gösterdiği için bireyselleştirilmiş öğretim planı hazırlyyoruz (Ö3). Eğitim-Öğretim yılı başında öğrenci bazında ve Rehberlik Araştırma Merkezi (RAM) tarafindan matbu form ile şekillenen bu planla, öğrencilere fayda sağlanmaya çalı̧ıllyor. Yoğun ve sürekli dikkat isteyen derslerde, kaynaştırma öğrencilerinin dikkat süreleri de düşünüldü̈̆̈̈̈nde, onlar için zor ve sıkıcı bir ders olmaktadır. Bireyselleştirilmiş eğitim programında öğrencilerin bulundukları sinıf düzeyinin kazanımlar öğrencinin algısina göre işlendiğinden, ayrıca bir zamana ihtiyaç duyulmaktadır. Bu nedenlerle bireyselleştirilmiş eğitim programinda sinıf ortaminda toplu derslerde uygulanması son derece zordur (Ö4). Piyano dersi için her öğrenciye rehberlik öğretmeninin yönlendirmesiyle bireyselleştirilmiş eğitim programı hazırlıyorum (Ö5). Bu öğrenciler için özel bir program yok ama bireysel derslerde bireyselleştirilmiş eğitim programı hazırlıyoruz (Ö6).

Öğrencilerin yönlendirme durumlarına yönelik öğretmen görüşleri: ...... rehber öğretmenin yönlendirmeleriyle bireyselleştirilmiş eğitim plan hazırlyyoruz (Ö2). Piyano dersi için her öğrenciye rehberlik öğretmeninin yönlendirmesiyle bireyselleştirilmiş eğitim programı hazırlıyorum (Ö5).

Müzik öğretmenlerinin özel gereksinimli öğrencilerine yönelik uygulanan program ve rehberlik hizmetleri çalışmaları ile ilgili görüşlerine ilişkin bulgular 1şı̆̆ında öğretmenlerden Ö5 destek eğitim odası uygulamasının gerçekleştirildiğini ancak öğrencilerde edinilmesi istenilen kazanımların sağlanamadığını ifade etmiştir. Çalışmaya katılan tüm müzik öğretmenleri özel gereksinimli öğrenciler için bireyselleştirilmiş eğitim programları hazırladıklarını ve uyguladıklarını belirtmişlerdir. Müzik öğretmenlerinden Ö2 ve Ö5 ise bireyselleştirilmiş eğitim programını okul rehberlik servisinin yönlendirmeleri doğrultusunda hazırladıklarını vurgulamışlardır. 


\section{Müzik Alanı Özel Gereksinimli Öğrencilerin Öğrenim Süreçlerine Yönelik Müzik Öğretmenlerinin Beklentileri Temasına Yönelik Bulguları}

Güzel sanatlar lisesi müzik öğretmenlerinin müzik alanı özel gereksinimli öğrencilerin öğrenim süreci beklentileri temasına yönelik görüşleri Tablo 5'te sunulmuştur.

Tablo 5

Müzik Öğretmenlerinin Müzik Alanı Özel Gereksinimli Öğrencilerinden Beklentileri Doğrultusunda Oluşturulan Tema, Kategori ve Kodlar

\begin{tabular}{llll}
\hline Temalar & Kategoriler & Kodlar & Öğretmenler \\
\hline Beklentiler & Kişisel Gelişim & Uyum sağlama & Ö1, Ö6, Ö4 \\
& Sosyal ilişkileri & Ö1, Ö6, Ö7, Ö4, Ö3, Ö5, \\
& geliştirme & Ö2 \\
& Kolektif çalışmaların & Ö4, \\
& parçası olabilme & Ö7, Ö4, Ö3, Ö5 \\
& Temel becerileri & Oeliştirme & Ö2, Ö3 \\
& Mutlu ve yararl1 & hissedebilme & Ö1, Ö5 \\
& İşitme & Ö4 \\
& Teori & Ö4 \\
& Solfej & Ö6, Ö1, Ö7, Ö5, Ö2 \\
\hline
\end{tabular}

Tablo 5 incelendiğinde müzik alanı özel gereksinimli öğrencilerin öğrenim sürecinde müzik öğretmenlerinin beklentileri uyum sağlama, sosyal ilişkiler geliştirme, kolektif çalışmaların parçası olabilme, temel becerileri geliştirme, mutlu ve yararlı hissedebilme, işitme, teori, solfej ve çalg1 performanslarının geliştirilmesi olarak belirtilmiştir. Öğretmenlerin "beklentiler" temasına ilişkin görüşleri aşağıda verilmiştir.

Öğrencilerin uyum sağlamalarına yönelik öğretmen görüssleri: Bu öğrencilerin çoğu uyum problemi ve kendilerini kontrol etmede sorunlar yaşamakta, benim beklentim akranlarn ile uyum sağlamaları, sosyal ilişkilerinin gelişmesidir (Ö1). Öğretim programına göre oluşturulmuş gerek bireyselleştirilmiş eğitim programı gerekse örtük programla planlanmış destek eğitim odası saatlerinde öğrenci bazında kişisel gelişimin üst düzeyde olmasını sağlamak. Ancak, bizden çok öğrenci beklentisinin oluşturulması gerekir. Bu da önceden RAM tarafindan ayrıntılı ölçümlerle beklentiler belirlenerek, öğrencilerin okullardaki eğitimine katkı să̆lamaları sağlanmalıdır (Ö4). Benim öğrencilerimden tek beklentim yaşıtlarına uyum să̆layarak sosyal ilişkilerini geliştirmeleridir (Ö6).

Öğrencilerin sosyal ilişkilerini geliştirme durumlarına yönelik öğretmen görüşleri: ........benim beklentim akranları ile uyum sağlamaları, sosyal ilişkilerinin gelişmesidir (Ö1). Öğretmenleri ya da arkadaşlarıla sosyal ilişkiler kurabilmesi (Ö2). ..... sosyal anlamda gelişmeleri (Ö3). .......̈̈̆grenci bazında kişisel gelişimin üst düzeyde olmasını sağlamak (Ö4). ........sosyal anlamda arkadaşlarn ile uyumlu müzik yapabilme becerileri kazanmaları beklentilerim arasında (Ö5). ..... sosyal ilişkilerini geliştirmeleridir (Ö6).

Öğrencilerin kolektif çalışmaların bir parçası olabilmelerine yönelik öğretmen görüşleri: ........kolektif çalışmaların parçası olabilmesi, kendini mutlu ve yararlı hissedebilmesi (Ö2). 
Öğrencilerin temel becerilerini geliştirmeye yönelik öğretmen görüşleri: Temel becerilerini geliştirerek öğrenme yeterliliklerine uygun gelişimlerini sağlamaları....(Ö3). ........öğrenci bazında kişisel gelişimin üst düzeyde olmasını să̆lamak (Ö4). Temel müzik becerilerini geliştirmeleri ve algzlamalar (Ö5). Bu öğrencilerin temel becerilerini geliştirmeleri (Ö7).

Öğrencilerin kendilerini mutlu ve yararlı hissedebilmelerine yönelik öğretmen görüssleri: ......... kendilerini işe yaramış ve mutlu hissedeceklerdir (Ö3). ....... kendini mutlu ve yararlı hissedebilmesi (Ö2).

Öğrencilerin müziksel işitme becerilerine yönelik öğretmen görüşleri: Öğretmenlerden 2'i bu öğrencilerin işitme performanslarının iyi olduğunu belirtmiştir. Kaynaştırma öğrencilerinin özellikle işitme becerileri oldukça iyi (Ö1). İşitme dersinde gayet başarnlı olabiliyorken (Ö5).

Öğrencilerin teorik uygulamalara yönelik öğretmen görüşleri: Teori ve uygulama derslerinde, teori yok denecek kadar az. (Ö4).

Öğrencilerin solfej eğitimine yönelik öğretmen görüşleri: ......solfej derslerinde son derece başarı sağlanmaktadır (Ö4).

Öğrencilerin çalgı hakimiyetine yönelik öğretmen görüşleri: Çalgı öğretmeni olarak özel gereksinimli öğrencime verdiğim eserler diğer sinıf düzeyindeki ögrrencilere verdiklerimden daha kolay olmasına rağmen beklenilen performansı karşılayamamaktadır (Ö1). ......gözlemlerime dayanarak bu öğrencilerin çalgılarına karşı tutum ve performansların düşük buluyorum (Ö2). Genel anlamda çalgı performansları gerekli öğretim programı olmadığı için çok yavaş ilerlemektedir (Ö3). ........piyano dersinde daha yavaş bir gelişim gösterebilmektedir (Ö5). Çalgı derslerinde öğrenciler farklı ilerleme kaydedebiliyorken bazı ögrenciler daha az ilerleme kaydetmektedir (Ö6). Özel gereksinimli öğrencim çalgı performans beklentimi karşılayamıyor. Verdiğim eserler akranlarına göre çok kolay olmasına rağmen öğrenme sürecinde oldukça zorlanıyor (Ö7).

Özel gereksinimli öğrencilerin öğrenme süreçlerine yönelik müzik öğretmenlerinin beklentileri temasına ilişkin elde edilen bulgular doğrultusunda müzik öğretmenlerinden Ö1, Ö6 ve Ö4 bu öğrencilerin akranlarına uyum sağlamalarının önemini vurgulamışlardır. Araştırmaya katılan öğretmenlerin hepsi ise özel gereksinimli öğrencilerin sosyal ilişkilerini geliştirmelerini ve bu kapsamda kişisel gelişimlerini en üst düzeye taşımalarını beklemektedirler. Öğretmenlerden Ö4, özel gereksinimli öğrencilerden kolektif çalışmalar yapabilecek düzeye gelmelerini öğretmenlerden Ö7, Ö4, Ö3 ve Ö5 ise özel gereksinimli öğrencilerinden temel becerilerini geliştirmelerinin beklentileri arasında olduğunu belirtmişlerdir. Öğretmenlerden 2'si özel gereksinimli öğrencilerin kendilerini mutlu ve yararlı hissetmelerinin gelişimleri için çok önemli olduğunu vurgulamışlardır. Özel gereksinimli öğrencilerin performanslarına yönelik beklentilerinde müzik öğretmenlerinden Ö4 özel gereksinimli öğrencilerin teori dersleri ile ilgili performanslarının çok zayıf olduğunu ancak solfej derslerinde başarılı olduklarını ifade etmiştir. Görüşmeye katılan çalg1 öğretmelerinden 5'i özel gereksinimli öğrencilerin çalg1 derslerinde beklenen performansı sergileyemediklerini belirtmişlerdir. 
Müzik Alanı Özel Gereksinimli Öğrencilerin Öğrenim Süreçlerine İlişkin Müzik Öğretmenlerinin Görüşleri Ölçme/Değerlendirme Teması Bulguları

Güzel Sanatlar Lisesi müzik öğretmenlerinin müzik alanı özel gereksinimli öğrencilerin ölçme/değerlendirme ile ilgili görüşleri Tablo 6’ da sunulmuştur.

Tablo 6

Müzik Öğretmenlerinin Müzik Alanı Özel Gereksinimli Öğrencilerin Ölçme/Değerlendirme Süreçlerine Yönelik Görüşleri Doğrultusunda Oluşturulan Tema, Kategori ve Kodlar

\begin{tabular}{|c|c|c|c|}
\hline Temalar & Kategoriler & Kodlar & Öğretmenler \\
\hline \multirow[t]{4}{*}{ Ölçme/Değerlendirme } & & Sinif seviyesi & Ö3, Ö6 \\
\hline & & Gelişim özellikleri & Ö1, Ö2, Ö7 \\
\hline & & Yapabilirlik düzeyi & Ö5 \\
\hline & & Gözlem raporu & Ö4 \\
\hline
\end{tabular}

Tablo 6 incelendiğinde müzik öğretmenleri özel gereksinimli öğrencilerinin ölçme ve değerlendirme sürecinde sınıf seviyelerinin, gelişim özelliklerinin, yapabilirlik düzeylerinin ve gözlem raporlarının önemine dikkat çekmişlerdir. Öğretmenlerin "ölçme/değerlendirme" temasına ilişkin görüşleri aşağıda verilmiştir.

Öğrencilerin sınıf seviyelerine yönelik öğretmen görüşleri: Bu öğrenciler sınıf seviyelerindeki öğrencilerle aynı değerlendirmeye tabii olmamalıdır (Ö3). Kendi seviyeleri üzerinden değerlendirilmelidir. Mesela 11.Sınıfa gelmiş bir öğrenci hala 9.Sınıf seviyesinde ise üstü beklenmemelidir. Çünkü ciddi anlamda seviye atlamakta güçlük çeken öğrenciler var şu durumda her öğrenciyi kendi seviyesine göre değerlendirmek doğru olur diyebiliriz (Ö6).

Öğrencilerin gelişim özelliklerine yönelik öğretmen görüşleri: Bence bu ögrencilerin özel durumları göz önüne alınarak farklı ölçme değerlendirme kriterleri doğrultusunda değerlendirilmesi gerekmektedir (Ö1). Esnek olmalıdır, öğrencinin kendi özel durumundaki gelişme değerlendirilmelidir ve bu değerlendirme daima pozitif olmalıdır (Ö2). $\mathrm{Bu}$ çocukların kendi sınıf düzeylerine göre değil de gelişim özelliklerine göre değgerlendirilmelerini doğru buluyorum (Ö7).

Öğrencilerin yapabilirlik düzeylerine yönelik öğretmen görüşleri: Her öğrencinin kendine özgü bir gelişim çizelgesi olmalı ve birbirleri ile kıyaslanmadan kendi yapabilirlik düzeyinin üstüne çıkıp çıkmadığı ölçülmeli ve bu doğrultuda çalışılmalıdır (Ö5).

Öğrencilerin gözlem raporlarına yönelik öğretmen görüşleri: Bireyselleştirilmiş eğitim programı ile belirlenmiş ünite/kazanımlar üzerinden, gerçekçi bir izleme ve değerlendirme yapılmalıdır. Bu öğrenciler diğer öğrencilerden farkl olarak gözlem yapılmalı ve bireysel izleme ile saptanan durum, nota dönüştürmeden bir gözlem raporu oluşturulmalıdır (Ö5).

Özel gereksinimli öğrencilerin ölçme/değerlendirmelerine yönelik müzik öğretmenlerinin görüşlerine ilişkin elde edilen bulgular doğrultusunda öğretmenlerden 2'i özel gereksinimli öğrencilerin öğrenim süreçlerine yönelik ölçme ve değerlendirme uygulamalarının sınıf düzeyinde yapılması gerektiğini belirtmişlerdir. Öğretmenlerden $3^{\prime} \ddot{u}$ bu öğrencilerin ölçme ve değerlendirme süreçlerinde gelişim özelliklerinin dikkate alınması gerektiğini vurgulamış., öğretmenlerden Ö5 ise özel gereksinimli öğrencilerin ölçme ve değerlendirme süreçlerinde yapabilirlik düzeyine vurgu yapmıştır. Öğretmenlerden Ö4 özel gereksinimli öğrencilerin ölçme ve değerlendirme süreçlerinde gözlem raporu tutmanın önemine değinmiştir. 
Müzik Alanı Özel Gereksinimli Öğrencilerin Öğrenim Süreçlerine İlişkin Süreç/Yaşanılan Zorluklar Teması Bulguları

Güzel Sanatlar Lisesi müzik öğretmenlerinin müzik alanı özel gereksinimli öğrencilerinin yaşadıkları zorluklar ile ilgili görüşleri Tablo $7^{\prime}$ de sunulmuştur.

Tablo 7

Müzik Öğretmenlerinin Müzik Alanı Özel Gereksinimli Öğrencilerin Yaşadıkları Zorluklara İlişkin Görüşleri Doğrultusunda Oluşturulan Tema, Kategori ve Kodlar

\begin{tabular}{llll}
\hline Temalar & Kategoriler & Kodlar & Öğretmenler \\
\hline Süreç/Yaşanılan & Öğrenci açısından & Dikkat eksikliği & Ö5, Ö6, Ö7 \\
Zorluklar & & Güdülenmekte zorlanma Ö6 \\
& & Sosyal uyumsuzluk & Ö5 \\
& Illetişim kurma becerisi & Ö4 \\
& Akran zorbalığ1 & Ö2 \\
& Bireysel çalışma & Ö6 \\
& problemi & \\
& Disiplin sorunlar1 & Ö1 \\
& \multirow{2}{*}{ Öğretmen açısından } & Özel alan yetersizliği & Ö2, Ö3 \\
& & Bireysel çalışma & Ö3, Ö7 \\
\hline
\end{tabular}

Tablo 7 incelendiğinde müzik öğretmenleri özel gereksinimli öğrencilerinin yaşadıkları zorluklar ile ilgili dikkat çekmişlerdir. Öğretmenlerin "ölçme/ değerlendirme" temasına ilişkin görüşleri aşağıda verilmiştir.

Öğrencilerin dikkat eksikliği durumlarına yönelik öğretmen görüşleri: .......derse konsantre olma süreci çok uzun olabiliyor (Ö5)........konsantrasyon eksikliğinden dolayı kasları ile ilgili problem yaşamaları ve tek başlarına çalışmakta zorluk çekmeleri diyebilirim (Ö6). Özel durumlarından kaynaklanan dikkat eksikliği sebebiyle ders işlenişinde zorlanmaktalar (Ö7).

Öğrencilerin güdülenmekte zorlanma durumlarına yönelik öğretmen görüssleri: Benim derslerim açısından en büyük zorluk öğrencilerin kendilerini güdülemekte zorlanmalarn (Ö6).

Öğrencilerin sosyal uyumsuzluk durumlarına yönelik öğretmen görüşleri: Arkadaşları ile sosyal bir uyumsuzluk olabiliyor (Ö5).

Öğrencilerin iletişim kurma becerilerine yönelik öğretmen görüşleri: Öğretmenlerden Ö4 bu öğrencilerin iletişim kurma becerilerinin düşük olduğunu belirtmiştir. .....̈zzel gereksinimli öğrencilerle karşılaşılan en büyük zorluk olarak ifade edeceğim "iletişim kurma" sıkıntısıdır (Ö4).

Akran zorbalığına yönelik öğretmen görüssleri: Arkadaşlarıyla olan ilişkilerinde akran zorbalı̆̆ı yaşıyorlar (Ö2).

Öğrencilerin bireysel çalışma durumlarına yönelik öğretmen görüşleri: Öğretmenlerden Ö6 bu çocukların bireysel olarak kendi başlarına çalışma alışkanlıklarının olmadığını ifade etmiştir. ..... tek başlarına çalışmakta zorluk çekmeleri (Ö6).

Öğrencilerin disiplin sorunlarına yönelik öğretmen görüşleri: Disiplin sorunları genellikle bu öğrenciler kaynakl yaşanmakta (Ö1).

Öğrencilerin özel alan yetersizliklerine yönelik öğretmen görüşleri: Öğretmenlerden Süreçte karşılaşılan en büyük sorun öğretmenin kaynaştırma öğrencilerine 
karşı nasıl davranılacă̆̊ konusundaki bilgisizliği olabilir (Ö2). Bu öğrencilerin öğretmeni olarak bazen kendimi onlara nasıl hitap edeceğim konusunda eksik buluyorum (Ö3).

Öğrencilerin bireysel çalışma durumlarına yönelik öğretmen görüşleri: $\mathrm{Her}$ öğrenci ile bireysel çalışılmalı iki veya daha çok öğrenci ile ders yapılmamalıdır (Ö3). Bu ögrrencilerle mümkün olduğunca bireysel ders yapılmalı (Ö7).

Özel gereksinimli öğrencilerin yaşadıkları zorluklara ilişkin müzik öğretmenlerinin görüşleri doğrultusunda elde edilen veriler 1şında öğretmenlerden 3'ü bu öğrencilerin öğrenim süreçlerinde dikkat eksikliği kaynaklı sorunlar yaşadığını belirtmişlerdir. Öğretmenlerden Ö6, özel gereksinimli öğrencilerin ders esnasında güdülenmekte zorluk yaşadıklarını, Ö5 ise bu öğrencilerin akranları ile sosyal uyumsuzluk yaşadıklarını ifade etmiştir. Öğretmelerden Ö2, özel gereksinimli öğrencilerin yasadıkları en önemli zorluğun akranları tarafından kabul görülmemeleri olduğunu belirtilmiş, Ö1 ise özel gereksinimli öğrencilerin disiplin sorunları yasadıklarını vurgulamıştır. Öğretmenlerden 2'si özel gereksinimli öğrencilerin eğitimleri ile ilgili yeterli bilgi sahibi olmadıklarını belirtmişler, öğretmenlerden 2'si de bu öğrencilerle bireysel çalışmanın önemine vurgu yapmışlardır.

\section{Müzik Alanı Özel Gereksinimli Öğrencilerin Öğrenim Süreçlerine İlişkin Öneriler Teması Bulguları}

Güzel Sanatlar Lisesi müzik öğretmenlerinin müzik alanı özel gereksinimli öğrencilerinin öğrenim süreçlerine yönelik önerileri Tablo 8' de sunulmuştur.

Tablo 8

Müzik Öğretmenlerinin Müzik Alanı Özel Gereksinimli Öğrencilerin Öğrenim Süreçlerine Yönelik Önerileri Doğrultusunda Oluşturulan Tema, Kategori ve Kodlar

\begin{tabular}{|c|c|c|c|}
\hline Temalar & Kategoriler & Kodlar & Öğretmenler \\
\hline \multirow[t]{7}{*}{ Öneriler } & Özel Eğitim & Hizmet içi eğitim & Ö2, Ö3, Ö6, Ö7 \\
\hline & & Özel öğretim programı & Ö1 \\
\hline & & Özel öğretim yöntemleri & Ö5 \\
\hline & Öğretmen Motivasyonu & $\begin{array}{l}\text { Uzman müzik } \\
\text { öğretmenleri }\end{array}$ & Ö4, Ö1, Ö6 \\
\hline & & Ekonomik teşvik & Ö2 \\
\hline & Okul Desteği & Donanimlı personel & Ö2 \\
\hline & & Teknik altyap1 & Ö2 \\
\hline
\end{tabular}

Tablo 8 incelendiğinde müzik öğretmenlerinin özel gereksinimli öğrencilerinin öğrenim süreçlerine yönelik hizmet içi eğitim, özel öğretim programı, özel öğretim yöntemleri, uzman müzik öğretmenleri, ekonomik teşvik, donanımlı görevli ve teknik altyapı başlıkları altında önerilerde bulunmuşlardır. Öğretmenlerin "öneriler" temasına ilişkin görüşleri aşağıda verilmiştir.

Hizmet içi Eğitim: 6. maddedeki önerilere ek olarak gerek bireysel gerekse toplu derslerde kaynaştırma öğrencileriyle ders yapan öğretmenler bir taraftan gerekli eğitimlerle desteklenmeli. (Ö2). Bu öğrencilerin dersine giren öğretmenlerin özel eğitim dersleri ile ilgili kurs, seminer, akademik eğitim almaları gerekmektedir (Ö3). Güzel Sanatlar liseleri içinde kaynaştırma öğrencisi olacaksa eğer tüm öğretmenlerin kaynaştırma öğrencilerine derslerde yaklaşımı üzerine eğitim almaları gerektiğini düşünüyorum (Ö6). 
Özel öğretim programına yönelik öğretmen görüşleri: $B u$ öğrencilerin farklı ögretim programıyla bu alanda eğitim almış müzik öğretmenleri tarafindan öğrenim süreçlerini tamamlamalarının daha doğru olduğunu düşünüyorum (Ö1).

Özel öğretim yöntemlerine yönelik öğretmen görüşleri: Öğretmenin sabırla öğrenciyi tanıması ve ona uygun bir öğretme tekniği uygulaması gerekmektedir (Ö5).

Uzman müzik öğretmenlerinin eğitim sürecine katkılarına yönelik öğretmen görüşleri: Bu öğrencilerin farklı öğretim programıyla bu alanda eğitim almış müzik ögretmenleri tarafindan öğrenim süreçlerini tamamlamaların daha doğru olduğunu düşünüyorum (Ö1). Kaynaştırma öğrencilerinin okulda daha etkin fayda alabilmeleri için, Güzel Sanatlar Liseleri bünyesinde, özellikle Özel Ĕ̈itim Meslek Liselerinde bir süre çalışarak deneyim edinmiş ögretmenlerden oluşan 5-6 kişilik bir kadro kurularak, bu öğretmenlerin kaynaştırma öğrencilerinin teori, uygulama, çalgı ve bireysel ses eğitimi gibi alan derslerinin verilmesi daha etkili olacaktır (Ö4). Kesinlikle okullarda özel öğretim tekniklerinden anlayan bir öğretmen olması gerektiğini düşünüyorum (Ö6).

Öğretmenlere ekonomik teşvik uygulamalarına yönelik öğretmen görüşleri: Özel gereksinimli öğrencilerle ders yapan öğretmenler bir taraftan gerekli eğitimlerle desteklenirken ekonomik olarak da desteklenerek teşvik edilmelidir (Ö2).

Donanımlı personel uygulamalarına yönelik öğretmen görüşleri: Özel gereksinimli öğrencilerin bulunduğu okullarda bu konuda özel eğitim almış (ayrıca) rehber öğretmen, să̆lık görevlisi, hizmetli vs. kadroları bulunmalı (Ö2).

Okullardaki teknik altyapı durumlarına yönelik öğretmen görüşleri: Öğretmenlerden .......donanımlı ve güvenlikli revir, sağlık araç gereci gibi teknik altyapılar să̆lanmalıdır (Ö2).

Özel gereksinimli öğrencilerin öğrenim süreçlerine yönelik müzik öğretmenlerinin görüşleri doğrultusunda elde edilen bulgular 1şı̆̆ında öğretmenlerden 4' ü özel gereksinimli öğrencilerin eğitim ile ilgili hizmet içi kurslara alınmaları gerektiğini belirtmişlerdir. Öğretmenlerden Ö1, özel gereksinimli öğrenciler için ayrı bir öğretim programının uygulanması gerektiğini vurgulamış, Ö5 bu öğrencilerin eğitimlerinde özel öğretim yöntemlerinin uygulanması gerektiğini belirtmiştir. Öğretmenlerden 3'ü özel gereksinimli öğrencilerin eğitimini bu alanda uzmanlaşmış öğretmenlerin vermeleri gerektiğini ifade etmişlerdir. Öğretmenlerden Ö2 özel gereksinimli öğrencilerin öğretmenlerine ekonomik teşvik verilmesinin önemini belirtmiş, Ö2 özel gereksinimli öğrencilerin öğrenim gördükleri okullarda (sağlık, temizlik vb.) donanımlı görevlilerin ve araç-gereç gibi teknik alt yapıların bulunması gerektiğini ifade etmiştir.

\section{Sonuç, Tartışma ve Öneriler}

Müzik öğretmenleri ile yapılan görüşmeler doğrultusunda elde edilen bulgulardan aşağıdaki sonuçlara ulaşılmıştır:

1. Özel gereksinimli öğrencilerin yetenek sınavı kriterlerinin ve kontenjanlarının bu öğrencilerin özel durumları göz önünde bulundurularak belirlenmesi, bu öğrencilerin ilgi ve yetenekleri doğrultusunda istedikleri okullarda akranları ile birlikte eğitim almaları gerektiği sonucuna ulaşılmıştır.

2. Destek eğitim odalarının oluşturulması, bireyselleştirilmiş eğitim planlarının hazırlanarak rehberlik servisi tarafından gerekli yönlendirmelerin yapılmasının özel gereksinimli öğrencilerin eğitim-öğrenim sürecinin uygulama aşamaları olduğu sonucuna varılmıştır. 
3. Özel gereksinimli öğrencilerin sosyal ilişkiler kurabilmeleri, akranları ile ortak çalışmalar ve temel beceriler gerçekleştirebilmeleri ve en önemlisi de kendilerini mutlu ve yararlı hissedebilmelerinin müzik öğretmenlerinin beklentileri arasında olduğu sonucuna varılmıştır.

4. Özel gereksinimli öğrencilerin işitme performanslarını yeterli olduğu, teori, solfej ve çalgı hakimiyetlerinin ise geliştirilmesi gerektiği sonucuna ulaşılmıştır.

5. Özel gereksinimli öğrencilerin ölçme ve değerlendirme süreçlerinin, gelişim özellikleri, yapabilirlik becerileri ve sınıf seviyeleri göz önüne alınarak hazırlanması gerektiğini sonucuna ulaşılmıştır.

6. Özel gereksinimli öğrencilerin yaşadıkları zorlukların dikkat eksikliğinden kaynaklı güdülenmekte zorlanma, sosyal uyumsuzluk ve akranları ile iletişim kurmada güçlük olduğu sonucuna varılmıştır.

7. Müzik öğretmenleri özel gereksinimli öğrencilerin öğrenim süreçlerine yönelik çeşitli önerilerde bulunmuşlardır. Bunların, öğretmenlerin yeterliliklerinin arttırılması için hizmet içi kurslara katılımın sağlanması, özel gereksinimli öğrenciler için ayrı bir öğretim programının hazırlanması, bu öğrencilere yönelik özel öğretim yöntemlerinin geliştirilmesi ve kullanılması, bu alanda eğitim verecek uzman müzik öğretmenlerinin yetiştirilmesi ve bu öğretmenlere ekonomik teşvikler verilmesi, okulların teknik altyapılarının iyileştirilmesi ve donanımlı personel bulundurması olduğu sonucuna ulaşılmıştır.

Yapılan literatür çalışmasında benzer çalışmaların sonuçları değerlendirilmiştir. Birçok çalışmada müzik öğretmenlerinin özel gereksinimli öğrencilerin öğrenim süreçlerine yönelik yeterli bilgiye sahip olmadıkları ve bu konuda kendilerini yetersiz hissettikleri sonucuna varılmıştır. Parasız ve Demirci (2017) müzik öğretmenleriyle yaptıkları görüşmeler doğrultusunda elde ettikleri bulgular ışığında özel gereksinimli öğrencilere yönelik okulların ve sinıfların fiziki yönlerinin zayıf olduğunu, müzik öğretmenlerinin özel gereksinimli öğrencilerin eğitimleri konusunda yeterli bilgiye sahip olmadıklarını ve bireyselleştirilmiş eğitim programının rehber öğretmenler tarafından hazırlandığı için bu konu ile ilgili destek hizmeti alamadıklarını belirmişlerdir. Varış ve Hekim (2017) ise müzik öğretmenlerinin özel gereksinimli öğrencilerin eğitimlerinde özel eğitim öğretmenleri ile birlikte çalışarak derslerini planlamaları ve bu alan ile ilgili hizmet içi kurslara katılmaları, bu öğrencilerin seçiminde akranlarıyla eşit imkânlar verilerek gerekli müziksel yetenekleri ve yeterliliklerinin değerlendirilmeleri, müzik eğitimi sürecinde uygun öğretim materyallerinin kullanımı, okullardaki fiziki ortamlarının bu öğrencilere göre düzenlenmeye çalışılmasının sağlanması gerekliliğini vurgulamışlardır. İlker (2017), özel yetenekli ve aynı zamanda özel gereksinimli öğrencilerin eğitiminde amacın, sadece onların zayıf yönlerini geliştirmek değil aynı zamanda güçlü yönlerini destekleyecek stratejiler geliştirmek olduğunu, bunun da bireyselleştirilmiş eğitim programı (BEP), rehber öğretmenlerin desteği, okul dişı etkinlikler ve öğrencilerin ilgi alanlarına göre verilecek projeler ile gerçekleştirilebileceğini belirtmiştir. Güven ve Çevik (2011) ise lisans eğitiminde özel öğretim yöntemleri dersinde özel gereksinime ihtiyacı olan öğrencilere yönelik öğretim yöntemlerinin verilmesi, öğretmenlik uygulamasında özel gereksinimli öğrencilerin bulunduğu okulların tercih edilmesi, öğretmen adaylarına özel gereksinimli öğrencilere yönelik farklı bilgilendirmelerin, etkinlik, uygulama ve 
araştırmaların yaptırılmasının gerekliliğini vurgulamışlardır. Düzbastılar ve Eyüpoğlu (2019) müzik öğretmenlerinin çoğunun özel eğitim ile ilgili yeterli bilgiye sahip olmadıkları, bu sebeple öğrenci başarılarını nasıl değerlendireceklerini yeterli düzeyde bilmediklerini ifade etmişlerdir. Ayrıca özel eğitime gereksinim duyan öğrencilerle ders yapmanın özveri, sabır ve azim gerektirdiği belirtilmiştir. Bir başka araştırmada Akıncı ve Alpagut (2019) müzik öğretmenlerinin özel gereksinimli öğrencilerin müzik eğitimleri konusunda yeterli bilgiye sahip olmadıkları ve bu konu ile ilgili sorunlar yaşadıklarını ifade etmişlerdir.

Araştırmada elde edilen sonuçlar doğrultusunda aşağıdaki önerilerde bulunulmuştur:

1. Müzik alanında özel yeteneğe sahip olan ve güzel sanatlar liselerinde öğrenim görmek isteyen bu öğrencilerin yetenek sınavı kriterleri ve kontenjanları bu öğrencilerin özel durumları göz önünde bulundurularak düzenlenebilir.

2. Özel gereksinimli öğrencilerin öğrenim sürecine yönelik planlanacak uygulamaların bunları gerçekleştirecek öğretmenler tarafından daha iyi bilinmesinin hem öğretmen hem de öğrenci açısından yararlı olacağı düşünülmektedir.

3. Gerekli görülen her durumda öğretmenlerin eksikliklerini tamamlamak adına hizmet içi kurslar sıklaştırılmalı ve bu kurslara öğretmenlerin olabildiğince katılımı sağlanabilir.

4. Özel gereksinimli öğrencilerin ölçme ve değerlendirme aşamasında bu öğrencilerin öğrenim düzeyleri ve gelişim özelliklerinin daha çok dikkate alınması fayda sağlayabilir.

5. Eğitim fakültelerinin müzik öğretmenliği programlarında bu alanla ilgili ders içerikleri zenginleştirilebilir.

6. Bu öğrencilerin akranları ile birlikte eğitim gördükleri okulların fiziki ve sosyal yapılarının onlara uygunluğu yeniden gözden geçirilerek iyileştirilmesi yaralı olabilir.

7. Bu öğrencilerin akranlarına yönelik olarak özel gereksinimli öğrencilerin gelişimleri hakkında semineler düzenlenerek akran zorbalığının ortadan kaldırılmasına sağlanabilir.

8. Özel gereksinimli öğrencilerin mevcut potansiyellerinin tanılanması ve bu doğrultuda yetiştirilmeleri ilkesinin daha çok benimsenmesi ve uygulanması önerilmektedir.

\section{Kaynakça}

Akıncı, M. Ş. ve Alpagut, U. (2019). Müzik öğretmenlerinin kaynaştırma öğrencilerinin şarkı ve çalg1 eğitimlerine ilişkin görüşleri. Mersin Üniversitesi Eğitim Fakültesi Dergisi, 15(3), 909-930. doi: 10.17860/mersinefd.485509

Arı, A. (Ed.). (2019). Sosyal bilimlerde nitel araştırma yöntemleri. Konya: Eğitim Yayınevi.

Baltacı, A. (2018). Nitel araştırmalarda örnekleme yöntemleri ve örnek hacmi sorunsalı üzerine kavramsal bir inceleme. Bitlis Eren Üniversitesi Sosyal Bilimler Enstitüsü Dergisi, 7(1), 231-274. https:// doi.org/10.30803/adusobed.411797

Batu, S. ve Kırcaali İftar, G. (2011). Kaynaştırma. Ankara: Kök Yayıncılık. 
Batu, S. (2000). Özel gereksinimli öğrencilerin kaynaştırıldiğg bir kız meslek lisesindeki ögretmenlerin kaynaştırmaya ilişkin görüş ve önerileri (Yayınlanmamış doktora tezi). Eskişehir: Anadolu Üniversitesi.

Bütün, M. ve Demir, S. B. (Ed.). (2020). Nitel araştırma yöntemleri. Ankara: Siyasal Kitabevi.

Büyüköztürk, Ş., Kılıç Çakmak, E., Akgün, Ö. E., Karadeniz, Ş. ve Demirel, F. (2020). Ĕ̆itimde bilimsel araştırma yöntemleri. Ankara: Pegem Akademi.

Çepni, S. (2018). Araştırma ve proje çalışmalarına giriş. Bursa: Celepler Matbaacılık.

Darrow, A., A. (1999). Music educators' perceptions regarding the inclusion of students with severe disabilities in music classrooms. Journal of Music Therapy, 36(4), 254-273. https://doi.org/10.1093/jmt/36.4.254

Draper, E., A. (2020). Individual education programs: what music teachers need to know when working with students with disabilities. National association for music education. General Music Today. 33(3), 42-45. https:// doi.org/10.1177/1048371320902754

Dikmen, İ. H. (2018). (Ed.). Özel eğitime gereksinimi olan öğrenciler ve özel eğitim. Ankara: Pegem Yayıncilik.

Düzbastılar, M. ve Eyüpoğlu, G. (2019) Müzik öğretmenlerinin özel eğitime ihtiyacı olan öğrencilerin müzik öğretimine ilişkin tutumlarının incelenmesi. International Journal of Social Sciences and Education Research Online, 5(4). https:// doi.org/10.24289/ijsser.571267

Emir, S. (Ed.). (2017). Özel yeteneklilerin eğitiminde program tasarımı. Ankara: Pegem Akademi. https://doi.org/10.14527/9786052410943

Güler, A., Halıcıoğlu, M. B. ve Taşğın, S. (2015). Sosyal bilimlerde nitel araştırma. Ankara: Seçkin Yayıncılık.

Güven, E. ve Çevik, B. (2011). Müzik öğretmeni adaylarının kaynaştırmaya ilişkin görüşlerinin belirlenmesine yönelik bir çalışma (Balıkesir üniversitesi örneği). 2nd International Conference on New Trends in Education and Their Implications 27-29 April, Antalya: Turkey.

Güven, E. (2011). Müzik dersleri ve kaynaştırma uygulamaları. Kastamonu Eğitim Dergisi. 19(3), 709-718.

Melekoğlu, M. A. ve Sak, U. (2017). Öğrenme Güçlüğ̈̈ ve Özel Yetenek. Pegem Akademi: Ankara. https://doi.org/10.14527/9786053188049

Merriam, S. B. (2009). Qualitative research, a guide to design and implementation. http:/ / ndl.ethernet.edu.et/bitstream/123456789/49003/1/82.pdf.

MEB (2020b, Eylül 10). Millî eğitim bakanlı̆̆ı ortaöğretim kurumları yönetmeliği. https:/ / ogm.meb.gov.tr/www/yetenek-sinavi-ile-ogrenci-alacak-okullarabasvuru/icerik/717 adresinden alınmıştır.

MEB (2020a, Eylül 10). Özel ĕgitim hizmetleri yönetmeliği. https:/ / www.resmigazete.gov.tr/eskiler/2018/07/20180707-8.htm adresinden alınmıştır.

Parasız, G. ve Demirci, B. (2017). Müzik öğretmenlerinin kaynaştırma uygulamalarına ilişkin görüşleri (Erzurum ili örneği). Erzincan Üniversitesi Ĕ̈itim Fakültesi Dergisi, 19(3), 322-339. https:// doi.org/10.17556/erziefd.286784

Sönmez, V. (2002). Eğitim Felsefesi. Ankara: Anı Yayıncılık. 
Sönmez, V. ve Alacapınar, F. G. (2019). Örneklendirilmiş bilimsel araştırma yöntemleri. Ankara: Anı Yayıncılik.

Sucuoğlu, B. (2006). Etkili kaynaştırma uygulamaları. Ankara: Ekinoks Yayınları.

Tanrıverdi Kış, a. (2011). Kaynaştırma uygulamaları ve özel eğitim uygulamaları. Ankara: Nobel Akademik Yayıncilik.

Tavşancıl, E. ve Aslan, A., E. (2001). Sözel, yazılı ve diğer materyaller için içerik analizi ve uygulama örnekleri. İstanbul: Epsilon Yayıncılık.

Varış, Y. A. ve Hekim, M. M. (2017). Özel gereksinimli bireyler ve müzik eğitimi. Gazi Ĕ̆itim Bilimleri Dergisi. 3(3), 29-42.

Yağar, F. ve Dökme, S. (2018). Niteliksel araştırmaların planlanması: araştırma soruları, örneklem seçimi, geçerlik ve güvenirlik. Gazi Să̆lık Bilimler Dergisi, 3(3), 1-9.

Yıldırım, A. ve Şimşek, H. (2000). Nitel araştırma yöntemleri. Ankara: Seçkin Yayınları.

Salman Yıkmış, M. (2020). Nitel araştırmalarda e-görüşme tekniği. Trakya Üniversitesi Sosyal Bilimler Dergisi. 22(1), 183-197. https:// doi.org/10.26468/trakyasobed.556296

Wong, M. W. and Chik, M. P. (2016). Inclusive education policy in the Hong Kong primary music classroom. Arts Education Policy Review. 117(2), 130-140. https:// doi.org/10.1080/10632913.2014.966286

\section{Summary}

\section{Introduction}

Educational environments should have a structure where students can express themselves freely, discover themselves and create opportunities to touch each individual sufficiently. This situation becomes even more important when considering the students with special needs. In education, generally, more emphasis is placed on studies that will improve the weaknesses of individuals with special needs. Although the possibility of individuals with special needs to have special talents at the same time is difficult to understand in society, there are special studies on this subject (Melekoğlu and Sak, 2017, p. 256).

In our education system, students with special needs who have special talents in different fields can study at formal education institutions that offer intensive programs in these fields together with their peers. Fine arts high schools are one of the institutions where these students with special talent in the field of music can receive education.

In the literature review of literature, studies on students with special needs and special talents at the same time were examined. Accordingly, it is seen that the studies on the subject of the research are insufficient. For this purpose, it is thought that taking the views of music teachers about the learning process of students with special needs in the music field of fine arts high school and developing suggestions to eliminate the deficiencies, if any, in line with these views will contribute positively to the process. In this study, it is aimed to evaluate school entrance and education practices for students with special needs, to determine how effective they are and to make various 
suggestions by determining the positive and negative aspects in line with the views obtained from the teachers who manage the process.

\section{Method}

This study is a qualitative research conducted in order to determine the views of music teachers about the learning processes of students with special needs in the music field of fine arts high schools. Interview method, one of the qualitative research methods, was used in this study. 7 music teachers working at Bursa Zeki Müren Fine Arts High School participated in the study. The research data were obtained in line with semistructured interview questions developed by the researchers by taking expert opinion. In the study, a personal information form was also used to determine the gender, educational status, years of service, work duration at fine arts high schools and with students with special needs of the music teachers working at the fine arts high school.

\section{Results}

As a result of the interviews with music teachers, it is seen that the exam criteria, quotas and determination of students' interests and talents come to the fore in the teachers' opinions about the talent exam of students with special needs in the field of music. In addition, music teachers emphasized the need for resource room, individualized education program and guidance practices in the students' learning process. Music teachers stated that their expectations from students with special needs were adaptation, developing social relationships, being a part of collective work, developing basic skills, feeling happy and useful and improving their hearing, theory, solfege and instrument performances. At the same time, music teachers described the difficulties experienced by students with special needs as difficulties in being motivated due to attention deficit, social maladjustment and difficulty in communicating with their peers. Evaluating the assessment and evaluation process of students with special needs, music teachers stated that this process should be evaluated considering the students' grade levels, developmental characteristics, ability levels and observation reports.

\section{Discussion}

In the light of the findings obtained in the study, research on students with special needs were examined. One of these studies was the study of 'Handicapped Person Who Need Special Education and Music Education' by Varış and Hekim (2017). In this study; it was emphasized that music teachers should work and plan their courses with special education teachers during the education of students with special needs and that they should attend in-service courses related to this field, that students should be given equal opportunities with their peers and the necessary musical abilities and competencies should be evaluated accordingly in the selection of these students, that appropriate teaching materials should be used in the music education process and that the physical environment in schools should be tried to be arranged according to these students (Varış and Hekim, 2017, p. 38). İlker (2017) emphasized that the aim in the education of gifted students with special needs should not only be to improve their weaknesses, but to develop strategies that will support the strengths of these students and he stated that this could be achieved with an individualized education program 
(IEP), support of counsellors, out-of-school activities and projects to be given according to the interests of the students.

One of the findings obtained in the study in line with the opinions of music teachers working with students with special needs is the evaluation of the learning processes of these students under the guidance of a different curriculum. Emir (2017) finds it important to prepare different curricula for gifted students with special needs in order to focus on the weaknesses and strengths of these children (Emir, 2017, p. 305).

\section{Pedagogical Implications}

In line with the results obtained in the research; it is stated that the talent examination criteria and quotas of students with special needs having special talent in the field of music and wanting to study at fine arts high schools should be arranged by considering the special conditions of these students, that the practices to be planned for the learning process should be well known by the teachers realizing them, that inservice courses should be organized in order to complete the shortcomings of teachers in every situation deemed necessary and teachers should attend these courses, that the education levels and developmental characteristics of these students should be taken into consideration more in the assessment and evaluation phase, that the content of the courses related to this field should be enriched in the music teaching programs of education faculties, that the physical and social structures of the schools where these students receive education together with their peers should be reviewed, that seminars should be organized on the development of students with special needs and contribute to the elimination of peer bullying and finally that the principle that students with special needs should be identified and trained accordingly should be adopted and applied more.

\section{Araştırmanın Etik Taahhüt Metni}

Bu araştırmada bilimsel, etik ve alıntı kurallarına uyulduğu; toplanan veriler üzerinde herhangi bir değişikliğin yapılmadı̆̆ı, karşılaşılacak tüm etik ihlallerde "Cumhuriyet Uluslararası Eğitim Dergisi ve Editörü 'nün" hiçbir sorumluluğunun olmadığı, tüm sorumluluğun sorumlu yazara ait olduğu ve bu çalışmanın herhangi başka bir akademik yayın ortamına değerlendirme için gönderilmemiş olduğu sorumlu yazar tarafından taahhüt edilmiştir.

\section{Authors' Biodata / Yazar Bilgileri}

Zeynep ÖZER, lisans öğrenimini Bursa Uludağ Üniversitesi Eğitim Fakültesi Müzik Eğitimi bölümünde, yüksek lisans öğrenimini ise Balıkesir Üniversitesi Sosyal Bilimler Enstitüsü Eğitim Bilimleri alanında tamamlamıştır. Yazar, Bursa Uludağ Üniversitesi Eğitim Fakültesi Müzik Eğitimi bölümünde doktora öğrenimine devam etmektedir. Halen Millî Eğitim Bakanlığı'nda öğretmen olarak görev yapmaktadır.

Zeynep Özer completed her BA at Bursa Uludağ University Faculty of Education Department of Music Education and her MA in the field of Educational Sciences at Balıkesir University Institute of Social Sciences. The author continues her PhD at Bursa Uludağ University Faculty of Education, Department of Music Education. She is still working as a teacher at the Ministry of Education. 
Rasim Erol DEMIRBATIR, lisans, yüksek lisans ve doktora eğitimini müzik eğitimi alanında Gazi Üniversitesi'nde tamamlamıştır. 1990 yılından itibaren Bursa Uludağ Üniversitesi Eğitim Fakültesi Müzik Eğitimi bölümünde görev yapmakta olup, halen Eğitim Fakültesi Dekan Yardımcılığ1 görevini sürdürmektedir.

Rasim Erol Demirbatir completed his BA, MA and $\mathrm{PhD}$ in the field of music education at Gazi University. He has been working at Bursa Uludağ University, Faculty of Education, Department of Music Education since 1990, and he still works as the Vice Dean of the Faculty of Education. 